\title{
Protective effects of Persea americana fruit and seed extracts against chemically induced liver cancer in rats by enhancing their antioxidant, anti-inflammatory, and apoptotic activities
}

\author{
Osama M. Ahmed ${ }^{1} \cdot$ Hanaa I. Fahim $^{1} \cdot$ Eman E. Mohamed $^{1} \cdot$ Adel Abdel-Moneim $^{1,2}$
}

Received: 19 January 2021 / Accepted: 23 January 2022 / Published online: 4 February 2022

(c) The Author(s) 2022

\begin{abstract}
This study aims to explore the chemopreventive mechanisms of hydroethanolic extracts from avocado (Persea Americana) in diethylnitrosamine (DEN)/2-acetylaminofluorene (2AAF)-induced hepatocarcinogenesis. Chemical induction of hepatocarcinogenesis was induced by intraperitoneal injection of DEN at $150 \mathrm{mg} / \mathrm{kg}$ body weight (b.w.) twice a week for a fortnight, followed by oral administration of $2 \mathrm{AAF}$ at $20 \mathrm{mg} / \mathrm{kg}$ b.w. four times a week for 3 weeks. Rats administered DEN/2AAF were orally treated with hydroethanolic extracts of avocado fruits and seeds at a dose of $50 \mathrm{mg} / \mathrm{kg}$ b.w. every other day for 20 weeks. Moreover, rats administered DEN/2AAF and treated with avocado extracts revealed a marked decrease in liver enzyme activities, total bilirubin levels, and elevated liver tumor markers, but revealed an increase in total protein and albumin levels. The hepatocytes with hyperchromatic and bile duct cystadenoma observed in the liver of rats administered DEN/2AAF were reduced due to treatment with avocado extracts. Furthermore, the treatments prevented the elevation of lipid peroxidation levels and ameliorated the lowered glutathione peroxidase, glutathione-S-transferase, superoxide dismutase activities, and glutathione content in the liver tissues. Also, antigen Ki-67, cyclooxygenase-2, and nuclear factor kappa-B expression levels were decreased, but of the suppressor proteins p53 and BAX levels were increased in the liver of rats administered DEN/2AAF and treated with avocado extracts. In conclusion, the current results demonstrated that avocado extracts could abate hepatocarcinogenesis in rats administered DEN/2AAF through activation of antioxidant, anti-inflammatory, and apoptotic properties.
\end{abstract}

Keywords Persea amricana $\cdot$ Diethylnitrosamine $\cdot$ Acetylaminofluorene $\cdot$ Hepatocellular carcinoma $\cdot$ Inflammation · Apoptosis

\section{Introduction}

Hepatocellular carcinoma (HCC) is the fifth most common cancer in the world and the second leading cause of mortality from cancer (World Health Organization. Global health observatory 2018) and it has been estimated to be responsible for nearly $9.1 \%$ of the total deaths $(746,000$

Responsible Editor: Mohamed M. Abdel-Daim

Adel Abdel-Moneim

adel_men2020@yahoo.com; adel.hassan@science.bsu.edu.eg

1 Physiology Division, Zoology Department, Faculty of Science, Beni-Suef University, Beni Suef, Egypt

2 Molecular Physiology Division, Faculty of Science, Beni-Suef University, Salah Salem St, Beni Suef 62511, Egypt deaths) (Ferlay et al. 2015). Hepatocarcinogenic and toxic effects of diethylnitrosamine (DEN) are validated animal model (Arboatti et al. 2018). DEN is found in pharmacological compounds, cosmetics, tobacco smoke, and cured and cooked meals (Dar et al. 2019). DEN was activated by cytochrome $\mathrm{P} 450$ enzymes, resulting in reactive electrophile species that produce oxidative stress, cytotoxicity, and carcinogenicity (Rajkapoor et al. 2005). Accordingly, DEN was shown to cause the production of free radicals, oxidative stress, and cell damage, and altering DNA structure (Bansal et al. 2000; Al-Rejaie et al. 2009). Interestingly, DEN was conducted to induce $\mathrm{HCC}$, while 2-acetylaminofluorene (2AAF) has been employed as a carcinogen promoter (Lto et al. 2003).

The antioxidants reduce the levels of oxidative stress via reactive oxygen species (ROS)-scavenging mechanisms (Simunkova et al. 2019). Lipids, nucleic acids, and proteins 
may be damaged by ROS, thereby altering their functions. Oxidative stress occurs when the equilibrium between ROS development and antioxidant protection is disrupted (Jelic et al. 2020). Unregulated and continuous liver imbalances among ROS production and ROS removal by protective mechanisms (antioxidants) lead to chronic disease and damage to vital biomolecules and cells (Reyes-Gordillo et al. 2017). Phytonutrients are herbal nutrients or phytochemicals with possible health benefits to preserve the well-being and normal functions of the body and to improve life expectancy (Memariani et al. 2020).

Avocado is a Central American tree; its fruits are widely used as a nutrition source and treatment of diseases. They have many biological benefits, like cholesterol-lowering, analgesic, and anti-inflammatory effects (Nicolella et al. 2017). Avocado fruit has nutrient contents such as vitamin B9, vitamin B6, vitamin C, vitamin K, dietary fiber, potassium, and copper (Dreher and Davenport 2013). It is commonly cultivated and eaten worldwide and has several health benefits (Mahmassani et al. 2018). In addition, avocado fruit contains several phytochemicals that have potential anticancer activity (Lu et al. 2005) such as avocation B which reduced human primary acute myelogenous leukemia without affecting normal peripheral blood stem cells (Lee et al. 2015). Avocado has been used in herbal medicine as an anticancer and was studied as a hepatoprotective agent (Mahmoed and Rezq, 2013). The anti-cancer effects of avocado seeds (lipid-rich extract) were reported in vitro against various types of cancer cell lines including Caco-2 (LaraMárquez et al., 2020), HCT116, and HePG2 (Alkhalaf et al., 2019). Moreover, Abozaid et al. (2018) stated in his preliminary study that avocado oil could be considered a promising therapeutic adjuvant against DEN-induced hepatocarcinogenesis. The protective anti-carcinogenic mechanisms of avocado hydroethanolic extracts in the DEN/2AAF-induced liver cancer model are not fully explored. Thus, our study aims to assess the anti-carcinogenic effect and explore the mechanisms of hydroethanolic extracts from avocado fruits and seeds in DEN/2AAF-induced hepatocarcinogenesis in Wistar rats.

\section{Materials and methods}

\section{Experimental animals}

Male adult Wistar rats, weighing 100-120 g, were included. The rats were purchased from the Egyptian Organization for Biological Products and Vaccines (VACSERA) Animal House Facility in Helwan, Cairo, Egypt. They were then kept under observation for 14 days before the beginning of the study to eliminate any infections. The rats were kept in polypropylene cages, with well-aerated stainless steel covers at normal temperature $\left(20-25^{\circ} \mathrm{C}\right)$ and regular daylight cycle (10-12 h/day) and a well-balanced standard diet ad libitum. All animal experiments were conducted in compliance with the general guidelines of animal care and the recommendations of the Experimental Animal Ethics Committee of Faculty of Science, Beni-Suef University, Egypt (BSU/ FS/2015/6).

\section{Chemicals and preparation of extracts}

DEN (\#N0756) and 2AAF (\#A7015) were obtained from Sigma Chemicals Co. (St. Louis, MO, USA) and stored at $2-4{ }^{\circ} \mathrm{C}$. Other chemicals were classified as of analytical grade. In November, avocado pear (Persea americana) fruits were obtained from a local market in Beni Suef, Egypt. They were authenticated by Prof. Dr. Mohamed Ahmed Fadl, Professor of Taxonomy, Botany Department, Faculty of Science, Beni-Suef University, Egypt.

Seeds have been isolated from fruits (pulps and peels), according to Ilochi and Chuemere (2019). In a well-aerated shade field, fruits and seeds were cut into pieces, dried for 15 days before being coarsely powdered, and then extracted with 11 of $70 \%$ ethanol $(1: 2 \mathrm{w} / \mathrm{v})$ for $72 \mathrm{~h}$ at room temperature $\left(25^{\circ} \mathrm{C}\right)$. The hydroethanolic extract from fruits and seeds was filtered with Whatman filter paper and concentrated by a rotary evaporator. The yield was determined to be $1 \%$, and the extracts were stored in glass bottles at $-18^{\circ} \mathrm{C}$, until used.

\section{Gas chromatography-mass spectrometry analysis}

Gas chromatography-mass spectrometry (GC-MS) is an analytical method that combines gas-chromatography and mass spectrometry features to identify different substances within a test sample. Additionally, it can identify trace elements in materials that were previously thought to have disintegrated beyond identification. It allows the analysis and detection of tiny amounts of a substance (Sparkman et al. 2011). A 7890A/5975C Inert MS-GC system with triple Axis Detector, Agilent Technologies (Germany), was used to analyze chemical constituents of avocado fruit and seed hydroethanolic extracts at the Central Laboratory of the Faculty of Postgraduate Studies for Advanced Sciences, Beni-Suef University, Egypt. The splitless mode was used to inject the hydroethanolic extract of fruits and seeds at a volume of $1 \mu \mathrm{l}$. A temperature of $250{ }^{\circ} \mathrm{C}$ was kept in the injection port. The oven temperature program begins at $120{ }^{\circ} \mathrm{C}$ and gradually rises to $220^{\circ} \mathrm{C}$ at a rate of $5{ }^{\circ} \mathrm{C} / \mathrm{min}$, followed by $8{ }^{\circ} \mathrm{C} / \mathrm{min}$ to $280{ }^{\circ} \mathrm{C}$ for $5 \mathrm{~min}$. Helium gas was utilized as a carrier gas at a flow rate of $1.0 \mathrm{ml} / \mathrm{min}$, and the total run time was $32.5 \mathrm{~min}$. The components were identified by comparing their mass spectra to the derivative spectra 
in the Library Search Report (C:IDatabaselNIST11.L; C:I Databaseldemo.l).

\section{Experimental design}

Four groups of ten adult male Wistar rats were allocated. The normal control group was Group I, while the other three groups were administered DEN intraperitoneally twice a week for a fortnight at a dose of $150 \mathrm{mg} / \mathrm{kg}$ body weight (b.w.), accompanied by oral gavage treatment with 2-AAF (20 mg/kg b.w.) four times a week for 3 weeks (De Lujan Alvarez et al. 2002). Group II received DEN/2AAF and served as a positive control group, and groups III and IV received DEN/2AAF and were simultaneously treated orally with avocado fruit and seed, respectively. Groups III and IV were each treated with avocado fruit and seed hydroethanolic extracts at a dose level of $50 \mathrm{mg} / \mathrm{kg}$ b.w. (Monika and Geetha 2016; Abdel-Moneim et al. 2017) every other day for 20 weeks (total duration of the study). Both groups I and II received the same volume of the vehicle (5 $\mathrm{ml} 1 \% \mathrm{CMC}$ ) in which the avocado fruit and seed were dissolved.

Diethyl ether was used to anesthetize the animals before they were sacrificed at the end of the experiment. Blood samples were obtained from the jugular vein and allowed to coagulate, then centrifuged at $3000 \mathrm{rpm}$ for $15 \mathrm{~min}$; sera were collected in sterile tubes and kept at $-20{ }^{\circ} \mathrm{C}$. After homogenizing $1 \mathrm{~g}$ of frozen liver tissue, $1 \%$ homogenate was produced in 10-ml phosphate buffer saline ( $\mathrm{pH} 7.4)$. Liver homogenates were centrifuged for $15 \mathrm{~min}$ at $3000 \mathrm{rpm}$. The supernatant is isolated and held at $-20^{\circ} \mathrm{C}$ until used to investigate oxidative stress and antioxidant biomarkers. A total of $3-\mathrm{mm}^{3}$ liver pieces were stored at $-70{ }^{\circ} \mathrm{C}$ in sterilized tubes until used for RNA isolation and RT-PCR assay.

\section{Biochemical investigations}

The activities of serum alkaline phosphatase (ALP) $(\# 11,592)$, alanine transaminase (ALT) $(\# 11,533)$, aspartate aminotransferase (AST) $(\# 11,531)$, and gamma-glutamyl-transpeptidase (GGT) $(\# 11,520)$ were estimated using reagent kits obtained from Biosystem S.A. (Spain). Serum total bilirubin $(\# 10,740)$, total protein $(\# 10,570)$, and albumin $(\# 156,004)$ levels were measured using Human Diagnostics (Germany) reagent kits. Serum carbohydrate antigen 19-9 (CA19-9) (\#MBS729408), carcinoembryonic antigen (CEA) (\#MBS700529), and alpha fetoprotein (AFP) (\#MBS034337) were assayed by Sandwich ELISA using kits from R\&D Systems (USA) according to the manufacturer's instructions.

The levels of lipid peroxidation (LPO) in liver homogenate were determined by measuring malondialdehyde (MDA) production using the technique of Yagi (1987). To summarize, the protein was precipitated by adding $0.15 \mathrm{ml}$ of $76 \%$ trichloroacetic acid (\#T6399, Sigma Chemicals Co., USA) to $1 \mathrm{ml}$ of liver homogenate. Then, $0.35 \mathrm{ml}$ of thiobarbituric acid was added, as a color-developing agent, to the separated supernatant. After incubation in a water bath at $80{ }^{\circ} \mathrm{C}$ for $30 \mathrm{~min}$, the formed faint pink color was detected at $532 \mathrm{~nm}$. The standard used was MDA (1,1,3,3-tetramethoxypropane). Following the procedure of Beutler et al. (1963), reduced glutathione (GSH) level in liver was evaluated by adding $0.5-\mathrm{ml} 5,5^{\prime}$-Dithiobis (2-nitrobenzoic acid) (\#D-8130, Sigma Chemicals Co., USA), Ellman's reagent (as a color-developing agent), and phosphate buffer solution ( $\mathrm{pH} 7$ ) to the homogenate supernatant after protein precipitation. At $412 \mathrm{~nm}$, the produced yellow color in the samples and GSH standard was compared to the blank. In addition, the activity of liver glutathione-S-transferase (GST) was measured in the presence of GSH and 1-chloro-2,4-dinitrobenzene (CDNB) dissolved in ethanol using the Mannervik and Guthenberg (1981) technique. The molar extinction coefficient of $9.6 \mathrm{mM}-1 \mathrm{~cm}-1$ was used in the calculations. In particular, $250 \mu \mathrm{l} \mathrm{CDNB}(4 \mathrm{mM})$ was added to a Wasserman tube containing $250 \mu \mathrm{l}$ sample, $250 \mu \mathrm{l} \mathrm{GSH}$ solution $(4 \mathrm{mM})$, and $250 \mu$ phosphate buffer ( $\mathrm{pH}$ 7.3). The developed color was assessed after $10 \mathrm{~min}$ of incubation at $25^{\circ} \mathrm{C}$.

The activity of liver glutathione peroxidase (GPx) was assessed using the Matkovics et al. (1998) method, which involves detecting the GSH that was converted to oxidized glutathione (GSSG) by the enzyme and subtracting it from the total. In a Wasserman tube containing 350- $\mu$ Tris buffer (pH 7.6), 50- $\mu$ l GSH solution (\#A2084, Applichem, Germany) (2 mM), and 50- $\mu \mathrm{l} \mathrm{H} 2 \mathrm{O} 2(3.38 \mathrm{mM}), 50-\mu \mathrm{l}$ homogenate supernatant was added. Then, after $10 \mathrm{~min}$ of incubation, the residual GSH content was determined at $430 \mathrm{~nm}$ using the previously reported technique for GSH measurement. The standard test was performed by adding $50-\mu l$ distilled water instead of $50-\mu l$ sample and the blank test was performed by adding 100- $\mu$ l distilled water instead of $50-\mu \mathrm{l}$ sample and 50- $\mu \mathrm{l} \mathrm{GSH}$ solution. Following the detection of residual GSH in the sample, the GSH converted to oxidized form (GSSG) and enzyme activity was estimated. Furthermore, the activity of superoxide dismutase (SOD) in the liver was measured using the technique of Marklund and Marklund (1974). The process is based on SOD inhibiting the auto-oxidation of pyrogallol. The process is dependent on the presence of superoxide ions. One unit of enzyme is defined as the quantity of enzyme that inhibits extinction changes by $50 \%$ in $1 \mathrm{~min}$ when compared to the control. Briefly, $50 \mu \mathrm{l}$ of pyrogallol $(10 \mathrm{mM})$ was added to $1 \mathrm{ml}$ of the homogenate supernatant in the presence of Tris buffer (pH 8). After adding pyrogallol, the initial absorbance was measured, as well as $10 \mathrm{~min}$ later. The enzyme activity and the inhibition of the formed yellow color at $430 \mathrm{~nm}$ were assessed. The biochemical investigation was measured by 
spectrophotometer, Humalyzer 3000, Human Diagnostics (Germany).

\section{RNA isolation and RT-PCR analysis in serum}

The total RNA was extracted from the liver using a Thermo Scientific GeneJET RNA purification kit (\#K0731) obtained from Thermo Fisher Scientific Inc. (Rochester, New York, USA) according to the method of Chomzynski and Sacchi (1987). A UV spectrophotometer was employed to determine the amount of extracted RNA. The purity of the extracted RNA was verified and must be ranged between 1.8 and 2.0. After that, $0.5 \mathrm{~g}$ of total RNA was added to produce cDNA. The produced cDNA was amplified using Thermo Scientific Verso 1-Step RT-PCR ReddyMix (\#F-580L) obtained from Thermo Fisher Scentific Inc. (Rochester, New York, USA) and specific primers provided from Biosesrch Technologies, South McDowell Blud, Petaluma, CA, USA. Ten $\mu \mathrm{l}$ of PCR products was examined on a 1.5\% agarose gel (\#Bio-41026) (Bioline Reagents Ltd, UK) stained with ethidium bromide (\#A1151) (Applichem, Germany) in 1X Tris Borate EDTA buffer (TBE) $\mathrm{pH}$ 8.3-8.5. The pair sequences of the following primers were used in this study: COX-2 was 5-AGA CAGATCATAAGCGAGGAC-3' (forward) and 5-CACTTG CATTGATGGTGGCTGT-3'(reverse) (Reuter et al. 1996; Ahmed et al. 2019) and NF- $\kappa$ B was 5'-AATTGCCCCGGC AT-3' (forward) and 5'ATGCGCCAATGCCCT-3' (reverse) (Habibi et al. 2016), while the primer sequences for p53 were 5'-GCTGCCCTCCCTTC TCCTAG-3' (forward) and 5'-CCCCGACTTTGGAGTAGTCTGA-3' (reverse) (AbdelMoneim et al. 2021). The primer sequences of $\beta$-actin were 5'-TCACTATCGGCAATGTGCGG-3' (forward) and 5'-GCTCAGGAGGAGCAATGATG-3' (reverse) (AbdelMoneim et al. 2021). The qPCR was performed, and the amplified data were analyzed using Livak and Schmittgen's (2001) method. The electrophoretic image was visualized using a gel documentation system, and the results and the density of bands of the detected gene were calculated relative to $\beta$-actin.

\section{RT-PCR analysis for miR-122}

MiRNeasy Mini kit (Qiagen, Düsseldorf, Germany) was used to extract total RNA from serum. Nanodrop and agarose gel electrophoresis $(\# 1,613,004)$ (Bio-Rad, USA) was performed to assess the amount and quality of RNA. The miScript II RT cDNA synthesis kit $(\# 4,366,596)$ (Qiagen, Düsseldorf, Germany) synthesized cDNA from total RNA $(1 \mu \mathrm{g})$ following the manufacturer's instructions. Additionally, each cDNA has been employed as a template for quantitative real-time RT-PCR and a primer specific for miR-122, F: 5'-TTGAATTCTAACACCTTCGTGGCTACA GAG-'3 and R: 5'-TTAGATCTCATTTATCGAGGGAAG
GATTG-'3, for U6, F: 5'CTCGCTTCGGCAGCACA-'3 and R: 5'-AACGCTTCACGAATTTGCGT-'3. All reactions were performed on step one plus (Applied Biosystem). The quantity of PCR was normalized to that for housekeeping gene U6. The $2-\Delta \Delta \mathrm{Ct}$ method was used for the relative quantification. The data are calculated as fold change differences compared to the relevant controls.

\section{Histopathological and immunohistochemical investigations}

Liver specimens from each animal were excised and decapitated by local dislocation and dissection of the head. After fixation in $10 \%$ neutral formalin buffered for $24 \mathrm{~h}$, pieces were handled with paraffin embedding procedure, dehydrated with ethyl alcohol, xylene clearing, and paraffin immersed. Liver pieces $\left(5 \mathrm{~mm}^{3}\right)$ were embedded in paraffin wax at $60{ }^{\circ} \mathrm{C}$. Sections of 4 micron thickness by slide microtome were stained with hematoxylin and eosin following Banchroft et al. (1996). In a microwave oven, tissue sections were incubated in a citrate buffer ( $\mathrm{pH}$ 6.0) for antigen recovery. Peroxidase activity in phosphate buffer saline ( $\mathrm{pH}$ 7.4) was quenched with $3 \% \mathrm{H}_{2} \mathrm{O}_{2}$ for 10 min. After 10-15 min of incubation with 10\% normal goat serum, non-specific binding sites were blocked. Sections were subsequently incubated with the primary antibody of Bax (\#A0207) or Ki-67 (\#A11390) (ABclonal Inc., China) overnight at $4{ }^{\circ} \mathrm{C}$ (diluted 1:200), then added two to three drops of the secondary antibody, horseradish peroxide-Polymer anti-Goat IgG, and were incubated at room temperature for $20 \mathrm{~min}$. Diaminobenzidine was employed in a color reaction to visualize peroxidase activity, and the sections were counterstained with hematoxylin. The intensity of immunohistochemistry staining for each marker was digitally recorded using image slave software (ImageJ) (Abramoff et al. 2004).

\section{Statistical methods}

Results were presented as mean \pm standard error. The oneway analysis of variance was used to determine statistical differences between groups (SPSS version 20 software, Chicago, IL, USA), followed by Duncan's test to compare different groups with significance set at $P<0.05$.

\section{Results}

GC-MS analysis of hydroethanolic extracts from avocado fruit and seed showed phytocomponents. The described phytocomponents are summarized in Tables 1 and 2 and shown in Fig. 1 ( $a$ and $b$ ) with their molecular weight (MW), molecular formula $(\mathrm{M} / \mathrm{F})$, retention time $(\mathrm{RT})$, and relative abundance represented as peak area $\%$ and activity. 
Table 1 The chemical profile of the avocado fruit hydroethanolic extracts as identified by GC-MS analysis

\begin{tabular}{llllll}
\hline No & RT & Name of the compound & Molecular formula & MW & Peak area \% \\
\hline 1 & 23.677 & 7-Hexadecyne & $\mathrm{C}_{16} \mathrm{H}_{30}$ & 222.41 & $1.925 \%$ \\
2 & 26.879 & No matches found & & & $6.994 \%$ \\
3 & 27.003 & $3,7,11$,Trimethyl-8,10- dodecedienyl acetate & $\mathrm{C}_{17} \mathrm{H}_{30} \mathrm{O}_{2}$ & 266.4 & $1.069 \%$ \\
4 & 29.088 & No matches found & & & $2.799 \%$ \\
5 & 32.772 & No matches found & & $6.625 \%$ \\
6 & 33.888 & No matches found & & $3.333 \%$ \\
7 & 34.594 & No matches found & & $5.377 \%$ \\
8 & 35.145 & 2-Methyl-3-(3-methyl-but-2-enyl)-2-(4- & $\mathrm{C}_{15} \mathrm{H}_{26} \mathrm{O}$ & 222.37 & $1.116 \%$ \\
& \multicolumn{1}{c}{ methyl-pent-3-enyl)-oxetane } & & & \\
9 & 35.302 & No matches found & $\mathrm{C}_{18} \mathrm{H}_{34}$ & & $1.189 \%$ \\
10 & 35.785 & 9-Octadecyne & & 250.5 & $8.988 \%$ \\
11 & 36.517 & No matches found & $\mathrm{C}_{11} \mathrm{H}_{20} \mathrm{O}$ & & $9.368 \%$ \\
12 & 36.956 & Cyclopropanemethanol & & 168.2 & $2.127 \%$ \\
13 & 37.45 & No matches found & & $5.794 \%$ \\
14 & 37.767 & No matches found & & & $1.811 \%$ \\
15 & 39.851 & 3-Undecanol & $\mathrm{C}_{13} \mathrm{H}_{28} \mathrm{O}$ & 200.3 & $1.448 \%$ \\
16 & 41.334 & Ethanol, 2-(9,12-octadecadienyloxy)- & $\mathrm{C}_{20} \mathrm{H}_{38} \mathrm{O} \mathrm{O}_{2}$ & 310.5 & $9.081 \%$ \\
17 & 42.86 & No matches found & & & $2.854 \%$ \\
18 & 45.693 & 6-Tetradecyne & $\mathrm{C}_{14} \mathrm{H}_{24}$ & 194.3 & $1.302 \%$ \\
19 & 46.886 & Bicyclo[10.1.0]tridec-1-ene & $\mathrm{C}_{13} \mathrm{H}_{22}$ & 178.3 & $1.059 \%$ \\
\hline & & & & &
\end{tabular}

Table 2 The chemical profile of the avocado seed hydroethanolic extract as identified by GC-MS analysis

\begin{tabular}{|c|c|c|c|c|c|}
\hline No & RT & Name of the compound & Molecular formula & MW & Peak area $\%$ \\
\hline 1 & 6.31 & 5-Hydroxymethylfurfural (5-HMF) & \multirow[t]{2}{*}{$\mathrm{C}_{6} \mathrm{H}_{6} \mathrm{O}_{3}$} & \multirow[t]{2}{*}{126.11} & $1.729 \%$ \\
\hline 2 & 12.81 & No matches found & & & $2.545 \%$ \\
\hline 3 & 16.12 & 2-n-Heptylfuran & \multirow[t]{4}{*}{$\mathrm{C}_{11} \mathrm{H}_{18} \mathrm{O}$} & \multirow[t]{4}{*}{166.2} & $3.82 \%$ \\
\hline 4 & 16.936 & No matches found & & & $3.43 \%$ \\
\hline 5 & 18.03 & No matches found & & & $1.295 \%$ \\
\hline 6 & 23.891 & No matches found & & & $1.317 \%$ \\
\hline 7 & 26.808 & $3,7,11$,Trimethyl-8,10- dodecedienyl acetate & \multirow[t]{3}{*}{$\mathrm{C}_{15} \mathrm{H}_{32} \mathrm{O}$} & \multirow[t]{3}{*}{225.4} & $3.641 \%$ \\
\hline 8 & 29.061 & No matches found & & & $3.301 \%$ \\
\hline 9 & 32.615 & No matches found & & & $4.56 \%$ \\
\hline 10 & 33.041 & 9-Octadecenamide & \multirow[t]{2}{*}{$\mathrm{C}_{18} \mathrm{H}_{35} \mathrm{NO}$} & \multirow[t]{2}{*}{281.4} & $1.135 \%$ \\
\hline 11 & 33.731 & No matches found & & & $2.977 \%$ \\
\hline 12 & 33.986 & 9-Octadecyne & \multirow[t]{2}{*}{$\mathrm{C}_{18} \mathrm{H}_{34}$} & \multirow[t]{2}{*}{250.5} & $3.672 \%$ \\
\hline 13 & 34.435 & No matches found & & & $2.75 \%$ \\
\hline 14 & 35.063 & 6,11-Undecadiene & \multirow[t]{3}{*}{$\mathrm{C}_{16} \mathrm{H}_{28} \mathrm{O}_{2}$} & \multirow[t]{3}{*}{252.3} & $3.22 \%$ \\
\hline 15 & 35.55 & No matches found & & & $5.246 \%$ \\
\hline 16 & 36.301 & No matches found & & & 4.917 \\
\hline 17 & 37.359 & Cyclopropanecarboxylic acid,undec-10-enyl ester & $\mathrm{C}_{15} \mathrm{H}_{26} \mathrm{O}_{2}$ & 238.37 & $4.661 \%$ \\
\hline 18 & 41.086 & 13-Tetradece-11-yn-1-ol & $\mathrm{C}_{14} \mathrm{H}_{24} \mathrm{O}$ & 208.3 & $1.476 \%$ \\
\hline 19 & 41.836 & gamma-Sitosterol & $\mathrm{C}_{29} \mathrm{H}_{50} \mathrm{O}$ & 414.7 & $1.677 \%$ \\
\hline 20 & 46.836 & Bicyclo[10.1.0]tridec-1-ene & $\mathrm{C}_{13} \mathrm{H}_{22}$ & 178.1 & $1.383 \%$ \\
\hline
\end{tabular}

\section{Effect on liver function}

Wistar rats administered DEN/2AAF for 20 weeks observed significant $(P<0.05)$ increases in serum AST,
ALT, GGT, and ALP activities and total bilirubin levels, while marked $(P<0.05)$ decreases in total protein and albumin levels were recorded compared to the normal group. Rats administered DEN/2AAF and treated 
Fig. 1 GC-MS analysis of A avocado fruit and $\mathbf{B}$ avocado seed hydroethanolic extracts

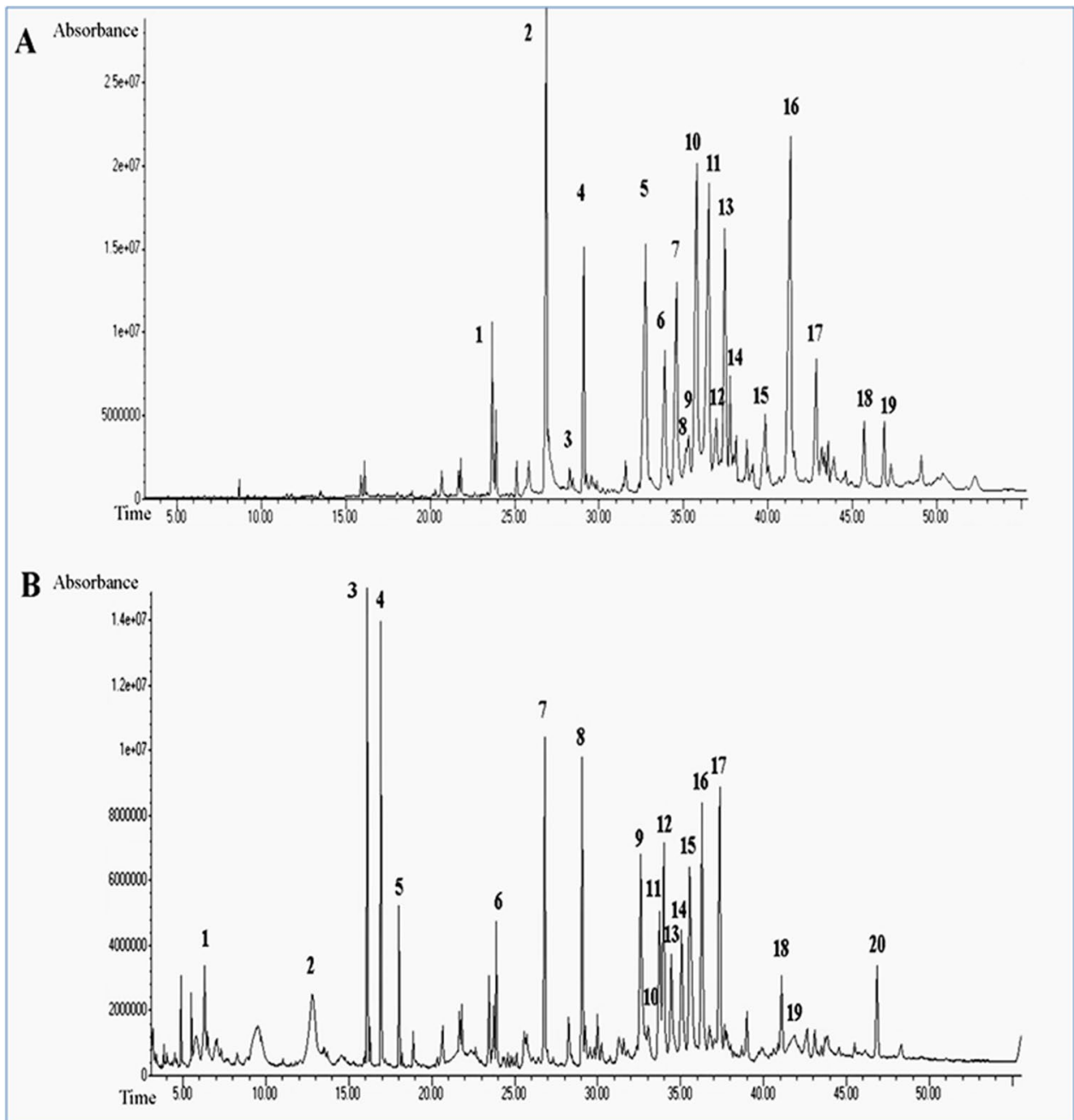

with hydroethanolic extracts of avocado fruits and seeds showed a noticeable decrease in the elevated activities of serum ALP, GGT, and ALT, and levels of total bilirubin compared to rats administered DEN/2AAF only. The treatment with avocado seed extract induced a marked increase in total serum protein concentrations, while the administration of avocado fruit extract showed a noticeable increase in serum albumin levels (Table 3 ).

\section{Effect on serum AFP, CEA, CA19.9, and miR-122 levels}

Treatment with DEN/2AAF induced a marked $(P<0.05)$ elevation in serum CEA, AFP, and CA19.9 levels compared to the normal group. Rats administered DEN/2AAF treated with hydroethanolic avocado extracts (fruit and seed) observed a noticeable amelioration in serum CEA, AFP, and CA19.9 levels. The avocado seed extract showed a more

Table 3 Effect of avocado fruit and seed hydroethanolic extracts on serum parameters related to liver function in rats administered DEN/2AAF

\begin{tabular}{llllllll}
\hline Group & $\begin{array}{l}\text { ALT } \\
(\mathrm{U} / \mathrm{L})\end{array}$ & $\begin{array}{l}\text { AST } \\
(\mathrm{U} / \mathrm{L})\end{array}$ & $\begin{array}{l}\text { ALP } \\
(\mathrm{U} / \mathrm{L})\end{array}$ & $\begin{array}{l}\text { GGT } \\
(\mathrm{mU} / \mathrm{dl})\end{array}$ & $\begin{array}{l}\text { Total bilirubin } \\
(\mathrm{mg} / \mathrm{dl})\end{array}$ & $\begin{array}{l}\text { Total protein } \\
(\mathrm{g} / \mathrm{dl})\end{array}$ & $\begin{array}{l}\text { Albumin } \\
(\mathrm{g} / \mathrm{dl})\end{array}$ \\
\hline Normal group & $44.5 \pm 2.07^{\mathrm{a}}$ & $132.8 \pm 5.20^{\mathrm{a}}$ & $157.6 \pm 17.01^{\mathrm{a}}$ & $18.00 \pm 2.73^{\mathrm{a}}$ & $0.56 \pm 0.02^{\mathrm{a}}$ & $8.6 \pm 0.32^{\mathrm{b}}$ & $4.21 \pm 0.10^{\mathrm{b}}$ \\
DEN/2AAF-CG & $66.5 \pm 4.31^{\mathrm{b}}$ & $156.5 \pm 4.86^{\mathrm{b}}$ & $310.8 \pm 17.48 \mathrm{~b}$ & $36.33 \pm 1.49^{\mathrm{b}}$ & $0.84 \pm 0.08^{\mathrm{b}}$ & $6.7 \pm 0.15^{\mathrm{a}}$ & $3.73 \pm 0.04^{\mathrm{a}}$ \\
DEN/2AAF+AFE & $51.3 \pm 5.30^{\mathrm{a}}$ & $139.5 \pm 9.17^{\mathrm{ab}}$ & $208.5 \pm 16.05^{\mathrm{a}}$ & $21.33 \pm 0.76^{\mathrm{a}}$ & $0.64 \pm 0.04^{\mathrm{a}}$ & $7.8 \pm 0.47^{\mathrm{ab}}$ & $4.16 \pm 0.15^{\mathrm{b}}$ \\
DEN/2AAF+ASE & $52.5 \pm 3.23^{\mathrm{a}}$ & $152.0 \pm 2.58^{\mathrm{b}}$ & $206.0 \pm 22.37^{\mathrm{a}}$ & $23.16 \pm 1.49^{\mathrm{a}}$ & $0.60 \pm 0.01^{\mathrm{a}}$ & $8.0 \pm 0.44^{\mathrm{b}}$ & $4.02 \pm 0.07^{\mathrm{ab}}$ \\
\hline
\end{tabular}

Data are expressed as mean \pm standard error. Number of detected samples in each group is six. Means, which share the same superscript symbol(s) in the same column, are not significantly different. $C G$, control group; $A F E$, avocado fruit extract; $A S E$, avocado seed extract. ALT, alanine transaminase; $A S T$, aspartate transaminase; $A L P$, alkaline phosphatase; $G G T$, gamma glutamyltransferase 
potent improvement in the elevated serum levels of AFP and CEA. In contrast, the avocado fruit extract showed a potential effect in decreasing serum CA19.9 levels. The administration of DEN/2AAF exhibited a significant increase in serum miR-122 expression levels compared to the normal group. However, rats administered DEN/2AAF and treated with avocado fruit and seed hydroethanolic extracts revealed a marked decrease in serum miR-122 expression levels compared to the DEN/2AAF-administered group (Table 4).

\section{Effect on liver oxidative stress and antioxidant defense system}

The injection of DEN/2AAF into Wistar rats induced an apparent $(P<0.05)$ increase in LPO levels and a marked decrease in GSH levels compared to normal rats. However, rats administered DEN/2AAF and treated with hydroethanolic avocado extracts (fruit and seed) revealed a significant decrease in LPO levels with a noticeable increase in the GSH levels compared to the DEN/2AAF-administered group. The avocado fruit extract revealed a more potent effect than avocado seed extract in decreasing the elevated liver LPO levels and increasing the lowered GSH levels (Table 5).

Notably, the treatment of Wistar rats with DEN/2AAF revealed a marked decrease in GPx, GST, and SOD activities compared with the normal rats. The administration of avocado fruit and seed hydroethanolic extracts revealed a significant increase in the lowered activities of SOD, GST, and
GPx, as compared to DEN/2AAF-administered group. The avocado fruit extract was more effective than seed extract in improving the antioxidant enzyme activities in DEN/2AAFadministered rats (Table 5).

\section{Effects on liver tissue mRNA gene expressions}

Administration of DEN/2AAF to Wistar rats induced a significant $(P<0.05)$ upregulation in COX-2 and NF- $\mathrm{KB}$ mRNA expressions relative to the normal group. DEN/2AAFadministered rats treated with avocado hydroethanolic avocado extracts observed a significant $(P<0.05)$ downregulation in the increased mRNA expressions of COX-2 and $\mathrm{NF}-\kappa \mathrm{B}$ relative to DEN/2AAF-administered group. Importantly, DEN/2AAF-administered rats showed a marked downregulation in p53 mRNA expressions relative to the normal group. The DEN/2AAF-administered group treated with avocado hydroethanolic extract exhibited a significant upregulation in p53 mRNA expressions when relative to the DEN/2AAF-administered group (Fig. 2).

\section{Immunohistochemical of BAX and Ki-67}

There was a significant decrease in hepatic BAX protein intensity in immunohistochemistry staining than in rats exposed to DEN/2AAF relative to the normal group. Conversely, in the group treated with avocado fruit and seed hydroethanolic extracts, there was a noticeable increase
Table 4 Effect of avocado hydroethanolic extracts on serum AFP, CEA, CA19.9, and miR-122 levels in rats administered DEN/2AAF

\begin{tabular}{lllll}
\hline Groups & $\begin{array}{l}\text { AFP } \\
(\mathrm{ng} / \mathrm{ml})\end{array}$ & $\begin{array}{l}\text { CEA } \\
(\mathrm{ng} / \mathrm{ml})\end{array}$ & $\begin{array}{l}\text { CA19.9 } \\
(\mathrm{U} / \mathrm{L})\end{array}$ & $\begin{array}{l}\text { miR-122 } \\
\text { (Relative to control) }\end{array}$ \\
\hline Normal group & $0.42 \pm 0.030^{\mathrm{a}}$ & $0.41 \pm 0.008^{\mathrm{a}}$ & $1.24 \pm 0.06^{\mathrm{a}}$ & $1.05 \pm 0.030$ \\
DEN/2AAF- CG & $4.40 \pm 0.101^{\mathrm{d}}$ & $3.73 \pm 0.363^{\mathrm{c}}$ & $3.29 \pm 0.34^{\mathrm{b}}$ & $5.60 \pm 0.513$ \\
DEN/2AAF+AFE & $1.97 \pm 0.0176^{\mathrm{c}}$ & $1.15 \pm 0.070^{\mathrm{b}}$ & $1.24 \pm 0.05^{\mathrm{a}}$ & $2.05 \pm 0.092$ \\
DEN/2AAF+ASE & $1.26 \pm 0.119^{\mathrm{b}}$ & $0.94 \pm 0.018^{\mathrm{ab}}$ & $1.41 \pm 0.09^{\mathrm{a}}$ & $2.03 \pm 0.154$ \\
\hline
\end{tabular}

Data are expressed as mean \pm standard error. Number of detected samples in each group is six. Means, which share the same superscript symbol(s) in the same column, are not significantly different. $C G$, control group; $A F E$, avocado fruit extract; $A S E$, avocado seed extract. $A F P$, alpha fetoprotein; $C E A$, carcinoembryonic antigen; $C A 19.9$, carbohydrate antigen 19.9

Table 5 The effect of avocado hydroethanolic extracts on liver LPO and GSH levels and GPx, GST, and SOD activities in rats administered $\mathrm{DEN} / 2 \mathrm{AAF}$

\begin{tabular}{lllcrc}
\hline Groups & $\begin{array}{l}\text { LPO (nmole MDA } \\
/ 100 \mathrm{mg} \text { tissue/hr) }\end{array}$ & $\begin{array}{l}\text { GSH (nmole } \\
/ 100 \mathrm{mg} \text { tissue) }\end{array}$ & GPx (mU/100 mg tissue) & GST (U/100 mg tissue) & SOD (U/g tissue) \\
\hline Normal group & $45.02 \pm 2.23^{\mathrm{a}}$ & $92.41 \pm 3.31^{\mathrm{c}}$ & $110.66 \pm 6.36^{\mathrm{b}}$ & $125.83 \pm 7.98^{\mathrm{b}}$ & $12.01 \pm 0.82^{\mathrm{c}}$ \\
DEN/2AAF- CG & $93.32 \pm 5.28^{\mathrm{b}}$ & $60.50 \pm 5.44^{\mathrm{a}}$ & $47.00 \pm 8.09^{\mathrm{a}}$ & $73.16 \pm 6.22^{\mathrm{a}}$ & $6.31 \pm 0.47^{\mathrm{a}}$ \\
DEN/2AAF+AFE & $47.70 \pm 2.70^{\mathrm{a}}$ & $85.66 \pm 3.61^{\mathrm{bc}}$ & $104.00 \pm 5.34^{\mathrm{b}}$ & $120.00 \pm 5.41^{\mathrm{b}}$ & $9.26 \pm 0.45^{\mathrm{b}}$ \\
DEN/2AAF+ASE & $60.06 \pm 2.45^{\mathrm{a}}$ & $79.33 \pm 2.45^{\mathrm{b}}$ & $93.50 \pm 3.56^{\mathrm{b}}$ & $114.90 \pm 3.78^{\mathrm{b}}$ & $10.07 \pm 0.31^{\mathrm{b}}$ \\
\hline
\end{tabular}

Results are expressed as mean \pm standard error. Each group has six samples. Means, which share the same superscript symbol(s) in the same column, are not significantly different. $C G$, control group; $A F E$, avocado fruit extract; $A S E$, avocado seed extract. $S O D$, superoxide dismutase, $G S T$, glutathione-S-transferase; $G P x$, glutathione peroxidase; $G S H$, glutathione; $L P O$, lipid peroxidation 
Fig. 2 Impact of avocado fruit and seed hydroethanolic extracts on liver tissue COX-2, NF-кB, and $\mathrm{P} 53$ mRNA expression in DEN/2AAF-administered rats. Means which have symbols(s) are not significantly different

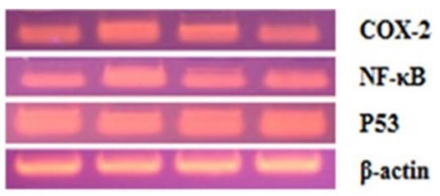

$\square$ Normal group (1)

回EN/2AAF-AFE (3) $\square \mathrm{DEN} / 2 \mathrm{AFF}-\mathrm{CG}$ (2)

$\square \mathrm{DEN} / 2 \mathrm{AAF}-\mathrm{ASE}(4)$

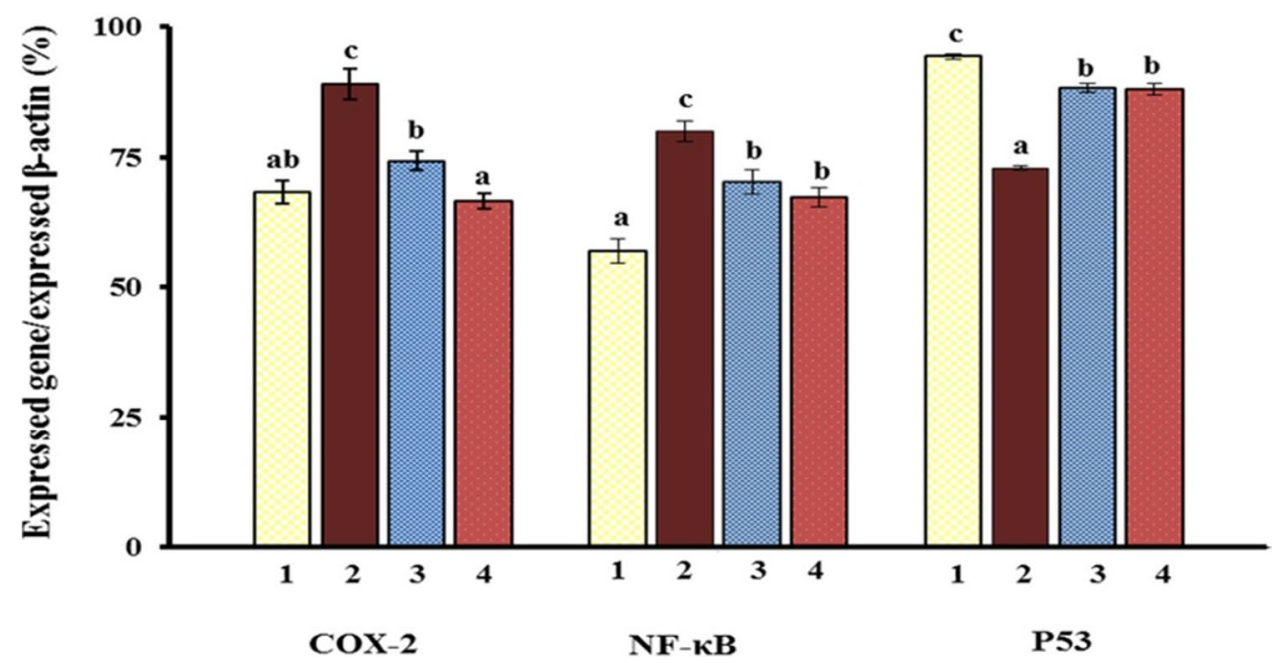

Fig. 3 Impact of avocado fruit and seed hydroethanolic extracts on the immunoreactivity of BAX (A) $(400 \times)$ and Ki-67 (B) $(400 \times)$ in rats administered DEN/2AAF

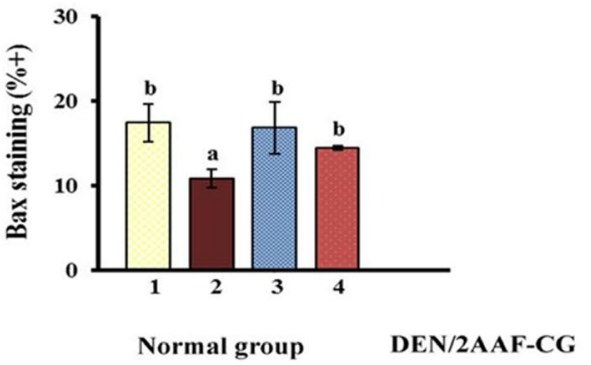

B aNormal group (1)

Bax
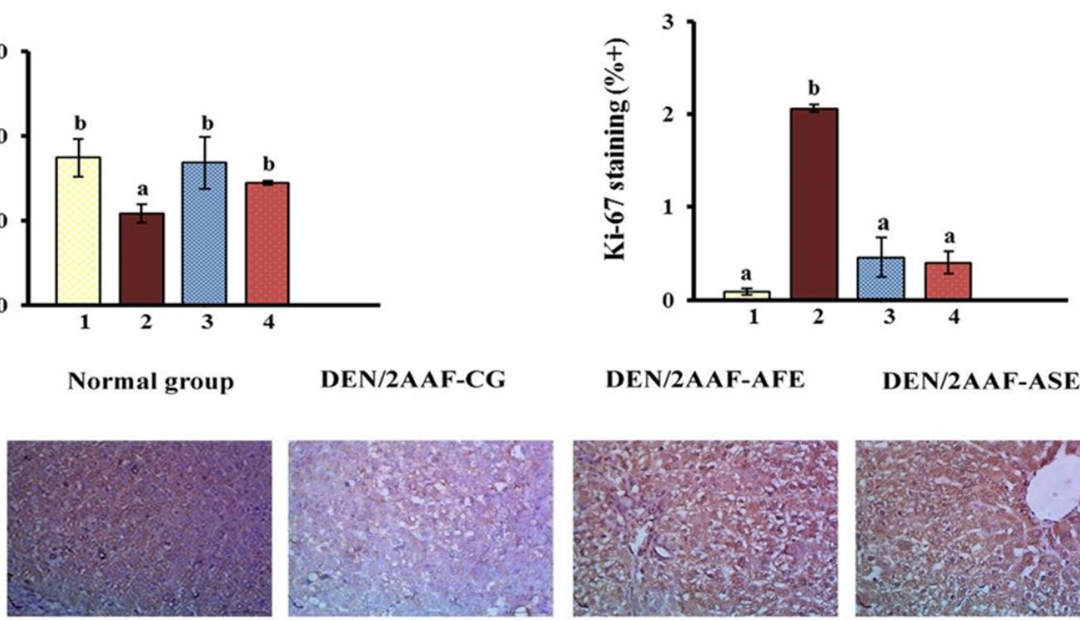

DEN/2AAF-AFE

DEN/2AAF-ASE
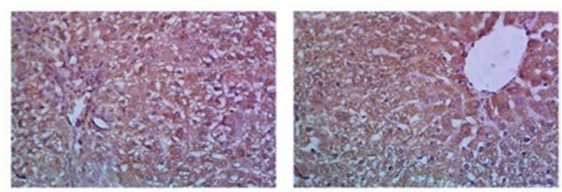

Ki-67
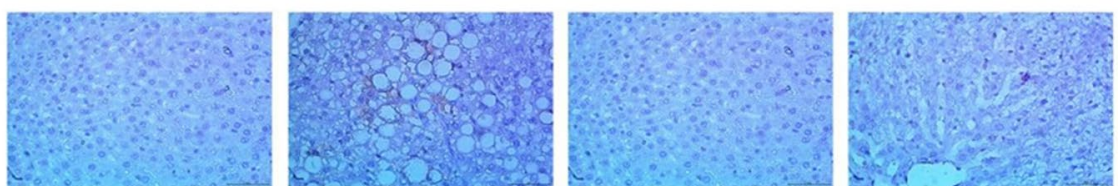
in BAX intensity staining than that of the DEN/2AAFadministered group (Fig. 3). Regarding intensity staining, a significant increase in hepatic Ki-67 intensity staining was more than that of animals exposed to DEN/2AAF compared to the normal rats. Otherwise, there was a marked decrease in Ki-67 intensity staining in the group treated with avocado fruit and seed hydroethanolic extracts than in the DEN/2AAF-administered rats (Fig. 3).

\section{The liver histopathological changes}

The histological examination of normal liver, DEN/2AAFadministered control, rats administered DEN/2AAF and treated with avocado fruit extract, and rats administered DEN/2AAF and treated with avocado seed extract was observed in Figs. 4, 5, 6, and 7, respectively. The liver sections of the normal group showed a normal organized histological structure of the hepatic lobule and normal
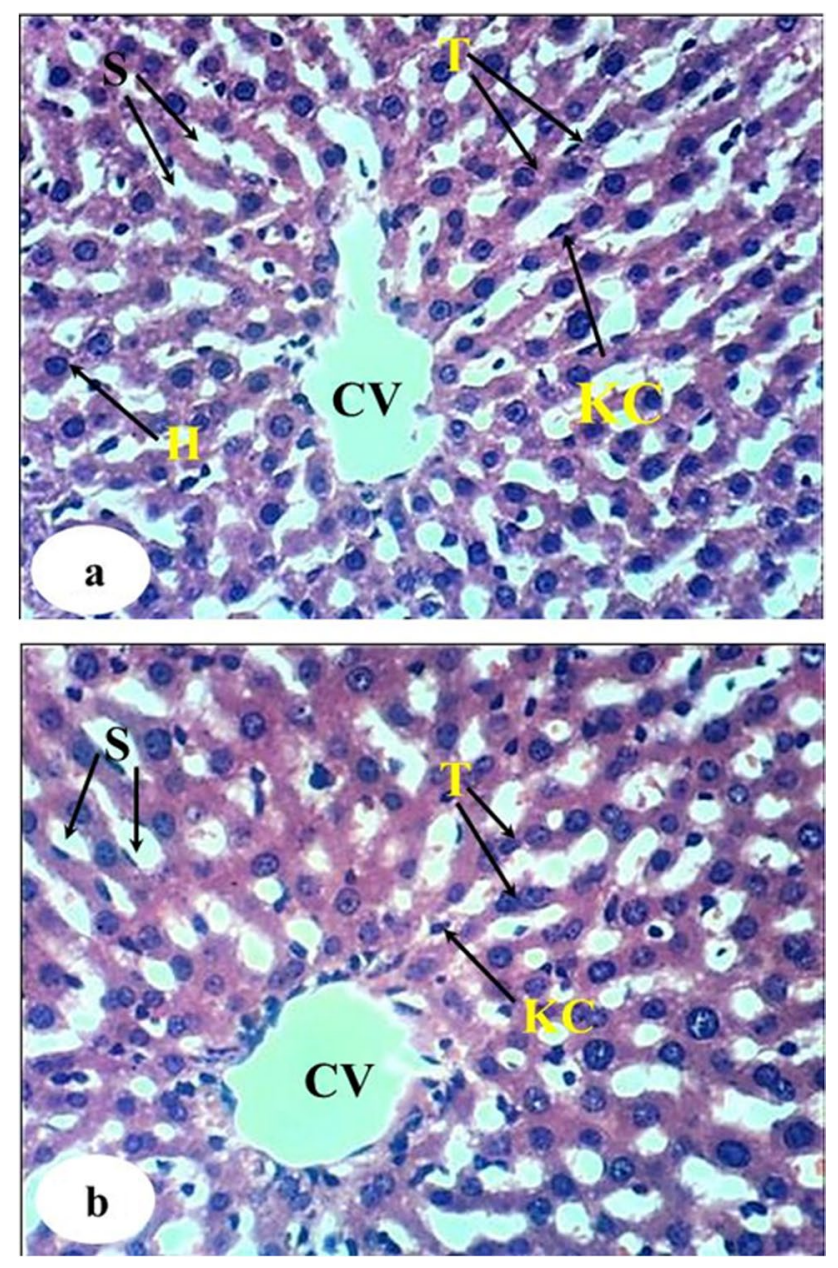

Fig. 4 Photomicrograph of liver sections of normal rats showing the normal histological structure of hepatic lobule, the central vein, the sinusoid (S), hepatic strand or trabeculae (T), Kupffer cells, and concentrically arranged hepatocytes $(\mathrm{H})(\mathrm{H} \& \mathrm{E}, \mathrm{X} 400)$ hepatocytes forming the hepatic cords (trabeculae), radiating from the central vein toward the periphery and alternate with narrow blood spaces known as sinusoids that are lined with Kupffer cells (Fig. 4a and b). The liver of rats administered DEN/2AAF showed cancerous lesions characterized by proliferated clear foci of hepatocytes with active vesicular nuclei (Fig. 5a); polyhedral clear hepatocytes (Fig. 5b); dysplastic, heavily proliferated, and vacuolated hepatocytes mitotic figures (Fig. 5c); parenchymatous steatohepatitis nodule in association with heavily proliferated eosinophilic hepatocytes (Fig. 5d); multiple biliary cysts in association with heavily proliferated hepatocytes (Fig. 5e); and large hyperchromatic karyomegalic nuclei with more than one prominent nucleolus (Fig. 5d). The liver of rats administered DEN/2AAF and treated with avocado fruit extract showed marked improvement as compared to DEN/2AAF-administered control but still depicted hepatic steatosis (Fig. 6a), cytoplasmic vacuolization of hepatocytes (Fig. 6b), and focal hepatic necrosis associated with inflammatory cell infiltration (Fig. 6c). Similarly, the liver of rats administered DEN/2AAF and treated with avocado seed extract exhibited marked amelioration but still have cytoplasmic vacuolization of hepatocytes (Fig. 7a) and focal hepatic necrosis associated with inflammatory cell infiltration (Fig. 7b) as well as some dysplastic proliferated hepatocytes with karyomegallic, misshaped, and hyperchromatic nuclei (Fig. 7c).

\section{Discussion}

The previous data indicated that DEN played a crucial role in inducing liver carcinogenesis through increased ROS generation and decreased liver antioxidant enzymes (Sivaramakrishnan et al. 2008). Elevated levels of prooxidants and different oxidative stress biomarkers induced significant damage in cells and tissues associated with cancer pathogenesis (Kruk et al. 2019). In our study, DEN/2AAF administration to rats led to a marked increase in enzymes activities of serum liver function (GGT, ALP, ALT, and AST) compared to the normal group. The current results agree with Mohamed and Amr (2013) and Gouegni and Abubakar (2013), who reported that liver function enzyme activities were significantly reduced after administration of avocado extracts. In our study, an elevated level of serum bilirubin and decreased total serum protein and albumin levels were observed in DEN/2AAF-administered rats compared to normal rats. The treatment of hydroethanolic avocado fruit and seed extracts improved total serum protein and albumin levels. Furthermore, oil extracted from avocado fruit revealed the beginning of the regeneration of liver function, thereby helped to increase total protein and albumin levels (Carvajal-Zarrabal et al. 2014). In this regard, avocado fruit extract improved the liver function 
Fig. 5 Photomicrographs of liver sections of rats administered DEN/2AAF showing proliferated clear foci of hepatocytes with active vesicular nuclei $(5 \mathrm{a}, 400 \times)$, polyhedral clear hepatocytes $(\mathrm{pCH})(5 \mathrm{~b}$, $400 \times$ ), dysplastic, highly proliferated, vacuolated hepatocytes with mitotic figures (MF) $(5 \mathrm{c}$, $400 \times)$, steatohepatitis nodule (St) in association with highly proliferated eosinophilic hepatocytes $(\mathrm{EH})(5 \mathrm{~d}, 400 \times)$, multiple biliary cysts in association with highly proliferated hepatocytes $(5 \mathrm{e}, 400 \times)$, and hyperchromatic karyomegalic nuclei with prominent more than one nucleolus $(5 \mathrm{~d}, 1000 \times)$
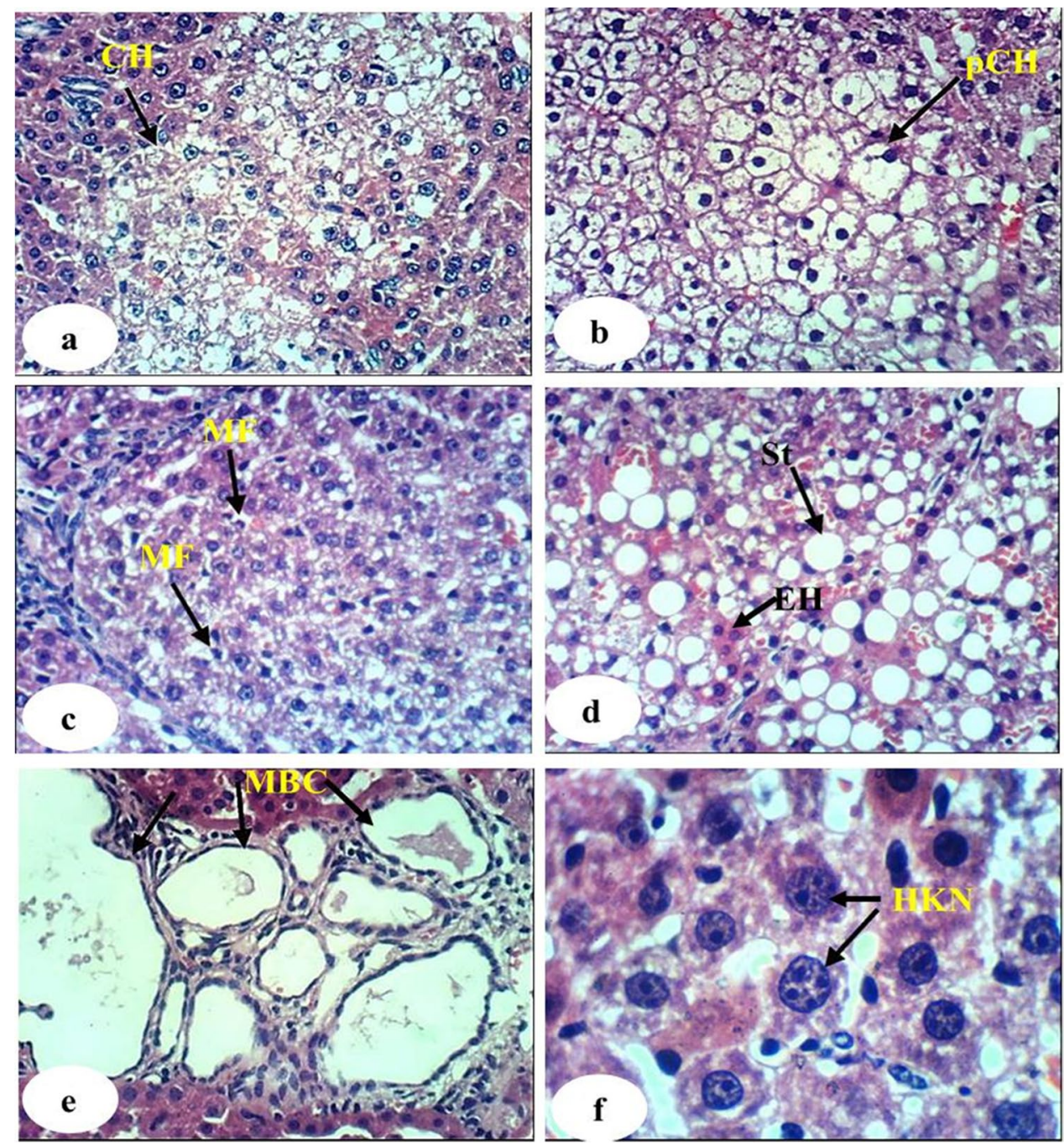

of DEN-administered rats due to the protective antioxidant mechanisms employed by both enzymatic and nonenzymatic substances such as phenolic and flavones (Rainey et al. 1994).

AFP is a well-known basic marker that increases in liver cancer, and CEA is also important in case of metastases to this organ (Snarska et al. 2006). Thus, AFP and CEA are effective biomarkers elevated in primary $\mathrm{HCC}$ and metastatic HCC (Qi et al. 2020). Importantly, AFP, CA19-9, and CEA together could help diagnose asymptomatic patients with primary hepatic cancer (Alhadi et al. 2019). In our study, the DEN/2AAF-administrated control group showed elevated liver tumor markers (CEA, AFP, and CA19.9) compared to the normal group. Numerous studies have shown that rat exposure to certain carcinogens, such as DEN, causes elevated levels of AFP (Sivaramakrishnan et al. 2008; Singh et al. 2009). Increased CEA and AFP levels support the incidence of $\mathrm{HCC}$ in the control group of DEN/2AAF; this finding is consistent with Gokuladhas et al. (2015), who reported that DEN induced an increase in HCC biomarkers.
MicroRNAs (miRNAs) are unique biomolecules that are exceptionally persistent against destruction (Link and Goel 2013). The miR-122 has been reported to have higher levels in serum of patients with HCC compared with healthy controls by various publications (Xu et al. 2011; Karakatsanis et al. 2013; El-Garem et al. 2014; Li et al. 2019). This study found that serum miR-122 was significantly elevated in DEN/2AAF-administered groups compared to the normal group. MiR-122 may be released into the bloodstream during hepatocellular injury due to its high expression in liver tissue (Hou et al. 2011). A possible relationship between AFP and miR-122 has been hypothesized in a mouse model (Ambade et al. 2016). The supplementation of hydroethanolic avocado fruit and seed extracts to rats administered DEN/2AAF significantly reduced the elevated serum AFP, CEA, CA19.9, and miR-122 levels indicating the anticancer activity of avocado treatments. These findings agree with Larijani et al. (2014), who described that avocado fruit extract is rich in phytochemicals that had a significant role in inhibiting 

liver sections of rats administered DEN/2AAF and treated with avocado fruit extract showing hepatic steatosis (St) $(6 a, 400 \times)$, cytoplasmic vacuolization of hepatocytes (CVH) $(6 \mathrm{~b}, 400 \times)$, and focal hepatic necrosis associated with inflammatory cells infiltration (IF) $(6 c, 400 \times)$
Fig. 6 Photomicrographs of the
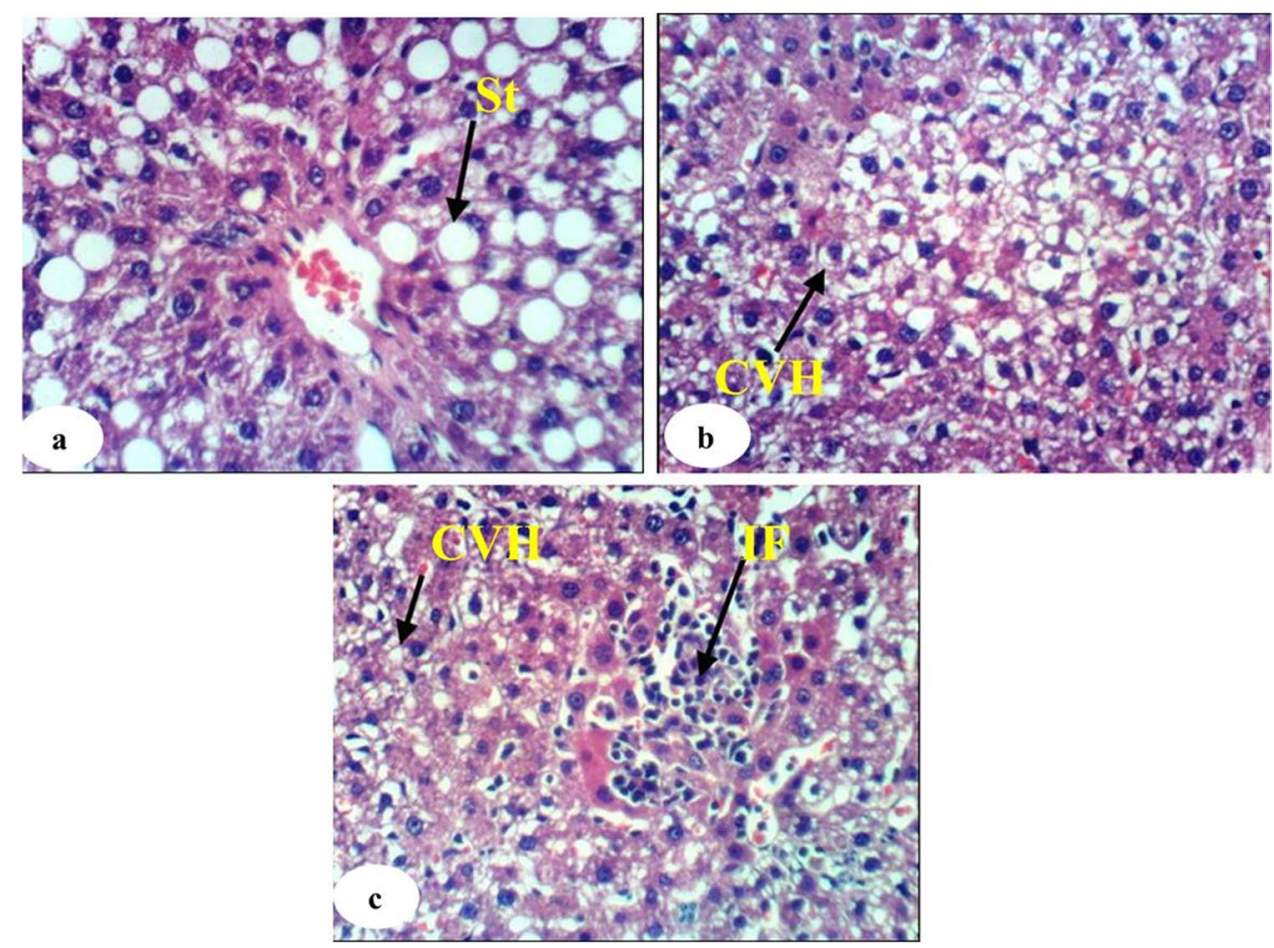

Fig. 7 Photomicrographs of the liver sections of DEN/2AAF rats treated with avocado seed extract showing cytoplasmic vacuolization of hepatocytes $(\mathrm{CVH})(7 \mathrm{a}, 400 \times)$ and focal hepatic necrosis associated with inflammatory cell infiltration (IF) $(7 b, 400 \times)$, and some dysplastic proliferated hepatocytes with karyomegallic, misshaped, and hyperchromatic nuclei (MHN) (7c, 400×)
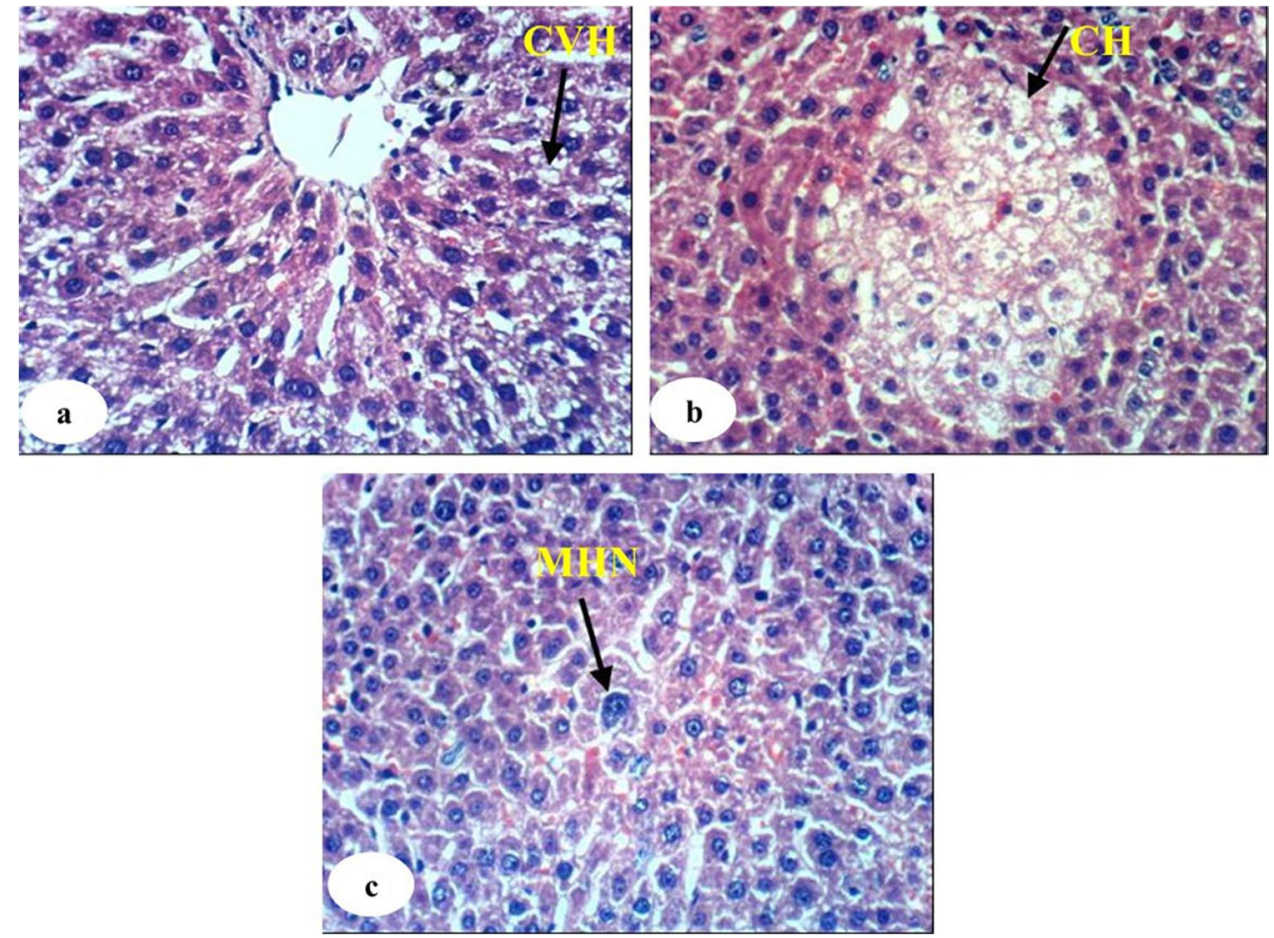

cancer cell growth. Also, avocado seed extract is richer in phenolic compounds that are potential anticancer agents (Platas et al. 2012). These elucidations are supported by Kushi et al. (2006), who stated that some avocado seed phytochemicals have anticarcinogen properties by blocking the action of carcinogens on their target organs and suppress cancer development.

Importantly, DEN/2AAF administration in rats induced an increase in LPO levels (Nafees et al. 2013), supported by the findings of Ahmed et al. (2019). LPO elevations 
induced a loss of the membrane property, and their reactive products may also damage other molecules (Thanan et al. 2015). In our research, enzymatic antioxidant (GPx, GST, and SOD) and nonenzymatic antioxidant (GSH) activities were decreased in rats administered DEN/2AAF compared to normal rats. Our data is consistent with Gokuladhas et al. (2015) results, who reported a reduction in the tissue antioxidants (enzymatic and nonenzymatic) in Wistar rats administered DEN. On the other side, the current investigation showed that hydroethanolic extracts of avocado fruit and seed supplementation reduced the liver LPO in rats administered DEN/2AAF. This result agreed with Hamouda et al. (2016), who suggested that avocado extract can protect the liver against oxidative stress, possibly through the antioxidant effects of its bioactive compounds.

In addition, there was a significant increase in enzymatic and nonenzymatic antioxidants in the liver of rats administered DEN and treated with hydroethanolic extracts of avocado fruits and seeds. These bioactive substances in avocado fruit extract have an antioxidant and free radical suppressing effect (Duester 2001). Notably, Mohamed and Amr (2013) reported an increase in liver GSH content and activities of GPx and SOD in carbon tetrachloride-intoxicated rats supplemented with avocado fruits. Similarly, phenolic compounds found in avocado seed extract were strong antioxidant agents because they could protect the human body from free radicals (Mushtaq and Wani 2013). Our results are consistent with the data reported by Sadek et al. (2012), who indicated that rats treated with avocado fruit and seed extracts observed a substantial increase in glutathione material compared to control rats. Notably, GC-MS is a valuable tool for the reliable identification of phytocompounds (SampathKumar \& RamaKrishnan 2011). GC-MS analysis of avocado fruit and seed hydroethanolic extracts showed phytocomponents, like 5-Hydroxymethylfurfural (5-HMF), 9-Octadecyne, and 9-octadecenamide. Previous results showed that 5-HMF, 9-Octadecyne, and 9-octadecenamide exhibited novel antioxidant activities (Cheng et al. 2008; Chew et al. 2009; Zhao et al. 2013). Also, 5-HMF displayed higher antiproliferative activities on human melanoma (Zhao et al. 2013).

Our data showed a significant increase in COX-2 mRNA expression in the liver of rats administered DEN/2AAF compared to normal rats. These data agree with Zhang et al. (2017), who found that DEN induces inflammation via oxidative-dependent way involving ROS and activated COX-2. Consistently, Chen et al. (2017) reported that COX-2 expression is upregulated markedly in HCC. In the current study, the data showed a marked increase in the levels of NF- $\kappa B$ mRNA expression in the liver of rats administered DEN/2AAF relative to normal rats. Consistent with our results, Sahin et al. (2014) found that DENinduced inflammation by ROS subsequently activated
$\mathrm{NF}-\kappa \mathrm{B}$, followed by the release of carcinogenic substances that led to HCC development.

Interestingly, the treatment of rats administered DEN/2AAF with hydroethanolic extracts from avocado fruits and seeds lowered the elevated COX-2 and NF- $\mathrm{\kappa B}$ mRNA expression, reflecting the antiinflammatory and anticancer efficacy of these treatments against hepatocarcinogenesis. Avocado fruit extract contains phytochemicals with potent free radical scavengers, including carotenoids (lutein, zeaxanthin, and $\alpha$ - and $\beta$-carotene) (Dreher and Davenport 2013). Additionally, $\beta$-Carotene, commonly found in natural foods, reduces the inflammation mediated by COX-2 and NF- $\mathrm{kB}$ in various disease signals (Aravindaram and Yang 2010). Furthermore, avocado seed extract is rich in polyphenols with antioxidant and antimicrobial activities (Rodríguez-Carpena et al. 2011), which have the same effect on COX-2 and NF- $\mathrm{KB}$. Our findings agreed with Hamouda (2015) data, who reported that rats administered DEN and treated with avocado fruit extract showed a significant decrease in COX-2 protein levels.

Apoptosis is a cancer chemoprevention process that eliminates the cells undergoing a neoplastic transformation in conditions where other defense mechanisms fail to obstruct carcinogenesis (Taha et al. 2009). The proapoptotic BAX protein is mainly involved in regulating the intrinsic pathway of apoptosis. The p53 gene is a tumor suppressor gene that activates BAX to cause apoptosis (Kelly and Strasser 2011). In response to DNA damage and oncogene activation, p53 plays an essential role in cellular stress response programs (Vousden and Prives 2009). According to several studies, p53 mutations are found in 30-60\% of HCC cases (Hussain et al. 2007). The present investigation showed a significant decrease in p53 and BAX levels due to DEN/2AAF administration in rats. These results agreed with $\mathrm{He}$ et al. (2016), who reported that p53 mutations are among the most common genetic alterations in human cancers, including HCC. Markedly, DEN decreases BAX expression in the liver of carcinogenic rats (Ou et al. 2015).

On the other hand, avocado fruit and seed hydroethanolic extracts elevated mRNA expression of p53 and BAX levels compared to the DEN/2AAF control group. In addition, Bonilla-Porras et al. (2014) reported that avocado extracts act as a proapoptotic compound and the current result indicated that avocado extracts can activate p53 and BAX expression. Besides, apoptosis appears to be an important target for avocado phytochemicals to selectively eliminate cancer cells from normal tissues (Ding et al. 2007). BAX and p53 are important mediators in the intrinsic pathway of apoptosis; their upregulation as a result of treatments of DEN/2AAF-administered rats with avocado fruit and seed extracts may indicate the possible role of apoptosis in the anticancer effects of these treatment agents. 
Fig. 8 Representative summary for the probable effects of avocado hydroethanolic extracts on hepatocarcinogenesis

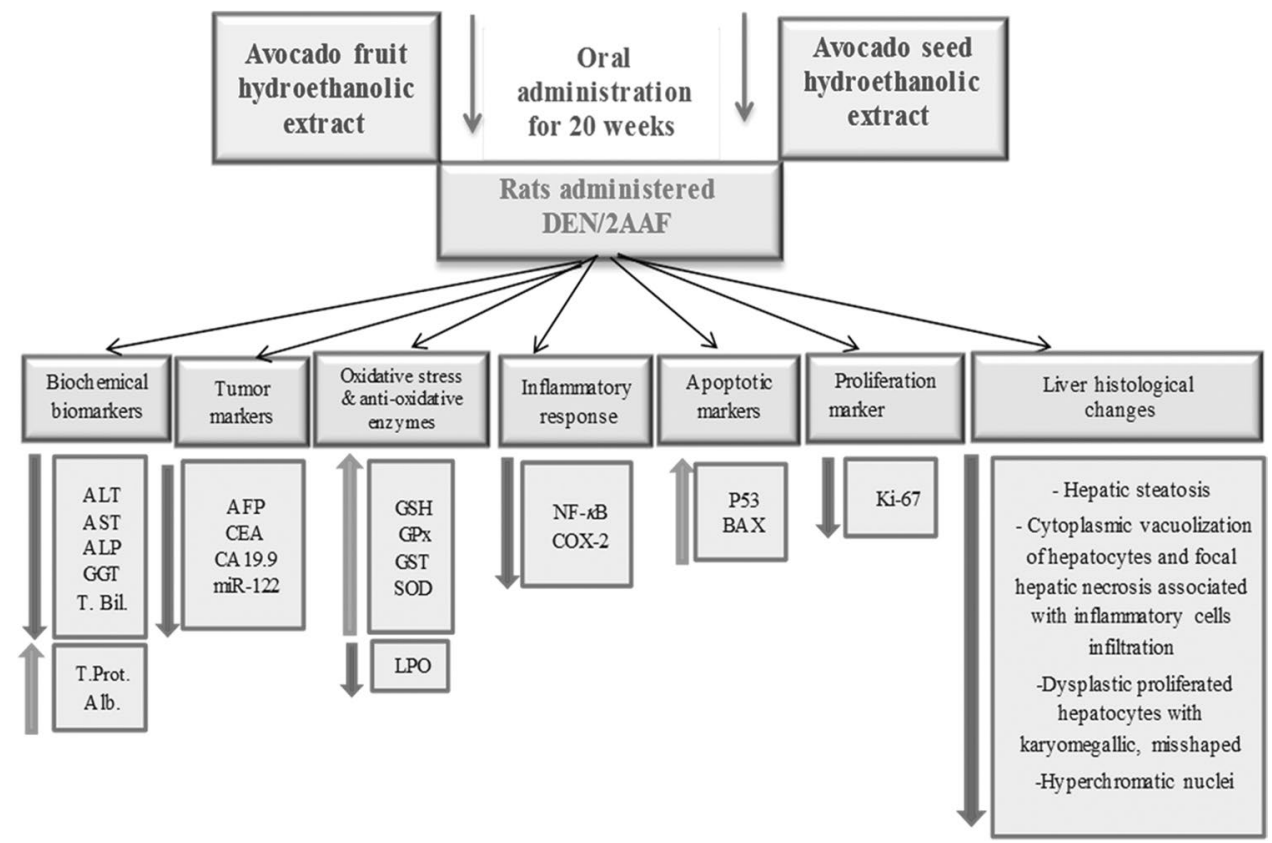

Cell proliferation is recognized to play a pivotal role in the various stages of cancer development. Because Ki-67 is a protein with an expression pattern fully dependent on cell proliferation, its expression is usually utilized as a cell proliferation indicator (Shi et al. 2015). In the current investigation, DEN/2AAF-induced hepatocarcinogenesis was associated with an increase in Ki-67 levels. These results followed previous research that revealed Ki-67 was overexpressed in DEN-induced hepatocarcinogenesis (Raghunandhakumar et al. 2013). Treatment with avocado fruit and seed shows depletion in Ki-67 levels. The biological effects of flavonoids include scavenging free radicals, NO production regulation, apoptosis induction, and cell proliferation inhibition (Yang et al. 2001).

\section{Conclusions}

In conclusion, administration of hydroethanolic extracts from avocado fruit and seed to rats administered $\mathrm{DEN} / 2 \mathrm{AAF}$ showed a decrease in liver COX-2, NF- $\kappa \mathrm{B}$, and Ki-67 levels and an increase in liver p53 and BAX levels, indicating attenuation in the liver inflammation with enhanced apoptosis pathway. Thus, hydroethanolic avocado extracts may have chemopreventive effects against DEN/2AAF-induced hepatocarcinogenesis and hepatocarcinoma via stimulation of antioxidant defense system, inhibiting inflammatory response, suppressing cell proliferation, and stimulating apoptosis. Proposed impacts of avocado hydroethanolic extracts on hepatocarcinogenesis are summarized in Fig. 8.

Acknowledgements The authors thank Prof. Dr. Kawkab A. Ahmed, Professor of Histopathology, Pathology Department, Faculty of Veterinary Medicine, Cairo University, Egypt, for help in examining and determining the lesions in the liver histological stained sections.

Author contribution Osama Ahmed, Hanaa Fahim, and Adel AbdelMoneim conceived and designed research. Eman Mohamed conducted experiments and analyzed data. Osama Ahmed, Adel Abdel-Moneim, and Eman Mohamed wrote the manuscript. All authors read and approved the manuscript and all data were generated in-house and that no paper mill was used.

Funding Open access funding provided by The Science, Technology \& Innovation Funding Authority (STDF) in cooperation with The Egyptian Knowledge Bank (EKB).

Data availability This published article includes all of the data generated or analyzed during this investigation.

\section{Declarations}

Ethics approval and consent to participate All animal procedures followed the general regulations and guidelines of the Experimental Animal Ethics Committee of the Faculty of Science, Beni-Suef University, Egypt, for the use and treatment of animals (ethical approval number: BSU/FS/2015/6). All of the authors consented to participate in the drafting of this manuscript.

Consent for publication Not applicable.

Competing interests The authors declare no competing interests. 
Open Access This article is licensed under a Creative Commons Attribution 4.0 International License, which permits use, sharing, adaptation, distribution and reproduction in any medium or format, as long as you give appropriate credit to the original author(s) and the source, provide a link to the Creative Commons licence, and indicate if changes were made. The images or other third party material in this article are included in the article's Creative Commons licence, unless indicated otherwise in a credit line to the material. If material is not included in the article's Creative Commons licence and your intended use is not permitted by statutory regulation or exceeds the permitted use, you will need to obtain permission directly from the copyright holder. To view a copy of this licence, visit http://creativecommons.org/licenses/by/4.0/.

\section{References}

Abdel-Moneim A, Ahmed O, Abd El-Twab S, Zaky M, Bakry L (2021) Prophylactic effects of Cynara scolymus L leaf and flower hydroethanolic extracts against diethylnitrosamine/acetylaminoflourene-induced lung cancer in Wistar rats. Enviro Sci Pollu Res 28(32):43515-43527

Abdel-Moneim A, Ahmed OM, Fahim HI, Mohamed EE (2017) The preventive effects of avocado fruit and seed extracts on cardionephrotoxicity induced by diethylnitrosamine/2-acetylaminoflurine in Wistar rats. Basic Sci Med 6(1):4-13

Abozaid OAR, Aziza SAH, Moawed FSM, Kasseb SG (2018) Avocado oil attenuates diethylnitrosamine induced-hepatic carcinogenesis. BVMJ 35(2):253-344

Abramoff M, Magelhaes P, Ram S (2004) Image Processing with Image. J Biophotonics Int 11(7):36-42

Ahmed OM, Ahmed AA, Fahim HI, Zaky MY (2019) Quercetin and naringenin abate diethylnitrosamine/ acetylaminofluorene-induced hepatocarcinogenesis in Wistar rats: the roles of oxidative stress, inflammation and cell apoptosis. Drug Chem Toxo. https://doi. org/10.1080/01480545.2019.1683187

Alhadi MI, Chutturghoon VK, Kwabena G et al (2019) Serum biomarkers AFP, CEA and CA19-9 combined detection for early diagnosis of hepatocellular carcinoma. Iran J Public Health 48(2):314-322

Alkhalaf MI, Alansari WS, Ibrahim EA, ELhalwagy MEA, (2019) Anticancer, antioxidant, anti-inflammatory, fatty acids, hydrocarbon. J King Saud Univ Sci 31(4):1358-1362

Al-Rejaie S, Aleisa A, Al-Yahya A et al (2009) Progression of diethylnitrosamine-induced hepatic carcinogenesis in carnitine-depleted rats. World J Gastroenterol 15:1373-1380

Ambade A, Satishchandran A, Szabo G (2016) Alcoholic hepatitis accelerates early hepatobiliary cancer by increasing stemness and miR-122-mediated HIF-1 $\alpha$ activation. Sci Rep 6:21340

Aravindaram K, Yang NS (2010) Anti-inflammatory plant natural products for cancer therapy. Planta Med 76:1103-1117

Arboatti A, Lambertucci F, Sedlmeier M et al (2018) Diethylnitrosamine increases proliferation in early stages of hepatic carcinogenesis in insulin-treated type 1 diabetic mice. BioMed Res Inter 2018:9472939

Banchroft JD, Stevens A, Turner DR (1996) Theory and practice of histological techniques. ${ }^{4 \text { th }}$ (Eds.) Churchil Livingstone, New York, London, San Francisco, Tokyo, 1996, pp, 766.

Bansal AK, Trivedi R, Soni GL, Bhatnagar D (2000) Hepatic and renal oxidative stress in acute toxicity of Nnitrosodiethylamine. Indian J Exp Boil 38(9):916-920

Beutler E, Duron O, Kelly BM (1963) Improved method for the determination of blood glutathione. J Lab Clin Med 61:882-888
Bonilla-Porras AR, Salazar-Ospina A, Jimenez-Del-Rio M, PereanezJimenez A, Velez-Pardo C (2014) Pro-apoptotic effect of Persea americana var. Hass (avocado) on Jurkat lymphoblastic leukemia cells. Pharm Biol 52:458-465

Carvajal-Zarrabal O, Nolasco-Hipolito C, Aguilar-Uscanga MG et al (2014) Effect of dietary intake of avocado oil and olive oil on biochemical markers of liver function in sucrose-fed rats. BioMed Res Inter 2014:595479

Chen H, Cai W, Chu ES et al (2017) Hepatic cyclooxygenase-2 overexpression induced spontaneous hepatocellular carcinoma formation in mice. Onco 36:4415-4426

Cheng MC, Lin LY, Yu TH, Peng RY (2008) Hypolipidemic and antioxidant activity of mountain celery (Cryptotaenia japonica Hassk) seed essential oils. J Agric Food Chem 56(11):3997-4003

Chew YL, Goh JK, Lim YY (2009) Assessment of in vitro antioxidant capacity and polyphenolic composition of selected medicinal herbs from Leguminosae family in Peninsular Malaysia. Food Chem 116:13-18

Chomzynski P, Sacchi N (1987) Single-step method of RNA isolation by acid guanidinium thiocyanate-phenol-chloroform extraction. Annu Rev Biochem 162:156-159

Dar K, Ali S, Ejaz M, Nasreen S et al (2019) In vivo induction of hepatocellular carcinoma by diethylnitrosoamine and pharmacological intervention in Balb C mice using Bergenia ciliata extracts. Brazilian J Bio 79(4):629-638

De Lujan Alvares M, Cerliani JP, Monti J et al (2002) The in vivo apoptotic effect of interferon alfa-2b on rat preneoplastic liver involves bax protein. Hepatol 35:824-833

Ding H, Chin YW, Kinghorn AD, D'Ambrosio SM (2007) Chemopreventive characteristics of avocado fruit. Semin Cancer Biol 17:386-394

Dreher ML, Davenport AJ (2013) Hass avocado composition and potential health effects. Crit Rev Food Sci Nutr 53(7):738-750

Duester KC (2001) Avocado fruit is a rich source of beta-sitosterol. J Am Diet Assoc 101:404-405

El-Garem H, Ammer A, Shehab H et al (2014) Circulating microRNA, miR-122 and miR-221 signature in Egyptian patients with chronic hepatitis C related hepatocellular carcinoma. World J Hepatol $6(11): 818-824$

Ferlay J, Soerjomataram I, Dikshit R et al (2015) Cancer incidence and mortality worldwide: Sources, methods and major patterns in GLOBOCAN 2012. Int J Cancer 136:E359-E386

Gokuladhas K, Jayakumar S, Rajan B et al (2015) Exploring the potential role of chemopreventive agent, hesperetin conjugated pegylated gold nanoparticles in diethylnitrosamine-induced hepatocellular carcinoma in male Wistar albino rats. Indian J Clin Biochem 31:171-184

Gouegni EF, Abubakar H (2013) Phytochemical, toxicological, biochemical and haematological studies on avocado (Persea americana) in experimental animals. NI FO J 31:64-69

Habibi F, Soufi F, Ghiasi R, Khamaneh A, Alipour M (2016) Alteration in inflammation-related miR-146a expression in NF-KB signaling pathway in diabetic rat hippocampus. Adv Pharm Bull 6(1):99-103

Hamouda AF (2015) Study on the effect of avocado on apoptosis, oxidative stress and injuries induced by diethylnitrosamine in rat liver. J Pharm Pharmacol 3:243-252

Hamouda AF, Sameeh MY, Shrourou RM (2016) Effect of avocado (Persea Americana), cabbage )Brassica Oleracea) and ginger (Zingiber Officinale) on rat liver and thyroid injuries induced by $\mathrm{CCl}_{4}$ (carbon tetrachloride). J Pharma Pharmacol 4:108-118

He XX, Zhang YN, Yan JW, Yan JJ, Wu Q, Song YH (2016) CP-31398 inhibits the growth of P53-mutated liver cancer cells in vitro and in vivo. Tumour Biol 37:807-815 
Hou J, Lin L, Zhou W et al (2011) Identification of miRNomes in human liver and hepatocellular carcinoma reveals miR-199a/b-3p as therapeutic target for hepatocellular carcinoma. Cancer Cell 19:232-243

Hussain SP, Schwank J, Staib F, Wang XW, Harris CC (2007) TP53 mutations and hepatocellular carcinoma: insights into the etiology and pathogenesis of liver cancer. Oncol 26:2166-2176

Ilochi O, Chuemere A (2019) Neuroprotective potential of avocado peel correlates with antioxidant status in starvation and refeeding in Wistar rats. Worldwide J Multidiscip Res Dev 5(1):70-74

Jelic MD, Mandic AD, Maricic SM, Srdjenovic BU (2020) Oxidative stress and its role in cancer. J Can Res Ther 24(40):4771-4778

Karakatsanis A, Papaconstantinou I, Gazouli M, Lyberopoulou A, Polymeneas G, Voros D (2013) Expression of microRNAs, miR21, miR-31, miR-122, miR-145, miR-146a, miR-200c, miR-221, miR-222, and miR-223 in patients with hepatocellular carcinoma or intrahepatic cholangiocarcinoma and its prognostic significance. Mol Carcinog 52(4):297-303

Kelly L, Strasser A (2011) The essential role of evasion from cell death in cancer. Adv Cancer Res 111:39-96

Kruk J, Hassan Y, Aboul-Enein HY, Kładna A, Bowser JE (2019) Oxidative stress in biological systems and its relation with pathophysiological functions: the effect of physical activity on cellular redox homeostasis. Free Radic Res 53:497-521

Kushi LH, Byers T, Doyle C (2006) American cancer society nutrition and physical activity guidelines advisory committee. CA Cancer J Clin 56:254-281

Lara-Márquez M, Báez-Magaña M, Raymundo-Ramos C et al (2020) Lipid-richextract from Mexican avocado (Persea americana var. drymifolia) induces apoptosis and modulates the inflammatory response in Caco-2 human colon cancer cells. J Funct Foods 64:10365810

Larijani LV, Ghasemi M, Kenari SA, Naghshvar F (2014) Evaluating the effect of four extracts of avocado fruit on esophageal squamous carcinoma and colon adenocarcinoma cell lines in comparison with peripheral blood mononuclear cells. Acta Med Iran 52:201-205

Lee E, Angka L, Rota S et al (2015) Targeting mitochondria with avocatin B induces selective leukemia cell death. Cancer Res 75:2478-2488

Li J, Jin B, Wang T et al (2019) Serum microRNA expression profiling identifies serum biomarkers for HCV-related hepatocellular carcinoma. Cancer Biomark 26(4):501-512

Link A, Goel A (2013) MicroRNA in gastrointestinal cancer: a step closer to reality. Adv Clin Chem 62:221-268

Livak KJ, Schmittgen TD (2001) Analysis of relative gene expression data using real-time quantitative PCR and the 2(-Delta Delta C (T) $(2-\Delta \Delta \mathrm{CT}))$ method. Methods 25(4):402-408

Lto N, Tamano S, Shirai T (2003) A medium-term rat liver bioassay for rapid in vivo detection of carcinogenic potential of chemicals. Cancer Sci 94(1):3-8

Lu QY, Arteaga JR, Zhang Q, Huerta S, Go VL, Heber D (2005) Inhibition of prostate cancer cell growth by an avocado extract: role of lipid-soluble bioactive substances. J Nutr Biochem 16:23-30

Mahmassani HA, Avendano EE, Raman G, Johnson EJ (2018) Avocado consumption and risk factors of heart disease: a systematic review and meta-analysis. Am J Clin Nutr 107:523-536

Mahmoed M, Rezq A (2013) Hepatoprotective effect of avocado fruits against carbon tetrachloride induced liver damage in male rats. World Applied Sci J 10:1445-1452

Mannervik B, Guthenberg C (1981) Glutathione transferase (human placenta). Meth Enzymol 77:231-235

Marklund S, Marklund G (1974) Involvement of the superoxide anion radical in the autoxidation of pyrogallol and convenient assay for superoxide dismutase. Eur J Biochem 47:469-474
Matkovics B, Kotorman M, Varga IS, Hai DQ, Varga C (1998) Oxidative stress in experimental diabetes induced by streptozotocin. Acta Physiol Hung 85:29-38

Memariani.Z, Farzaei MH, Ali A, Momtaz S (2020) Nutritional and bioactive characterization of unexplored food rich in phytonutrients. Phytonut in Food: 157-175.

Mohamed YM, Amr AR (2013) Hepatoprotective effect of avocado fruits against carbon male tetrachloride-induced liver damage in rats. World Applied Sci J 21:1445-1452

Monika P, Geetha A (2016) Effect of hydroalcoholic fruit extract of Persea americana Mill. on high fat diet induced obesity: a dose response study in rats. Indian J Exp Biol 54(6):370-378.

Mushtaq M, Wani SM (2013) Polyphenols and human health a review. Int J Pharm Bio Sci 4:338-360

Nafees S, Ali N, Rashid S, Hasan SK, Sultana S (2013) Chemopreventive effect of Bauhinia purpurea against chemically induced hepatocarcinogenesis via amelioration of oxidative damage, cell proliferation and induction of apoptosis in Wistar rats. Toxicol Inter 20:117-125

Nicolella HD, Neto FR, Corrêa MB et al (2017) Toxicogenetic study of Persea americana fruit pulp oil and its effect on genomic instability. Food Chem Toxicol 101:114-120

Ou XH, Lu Y, Liao LF et al (2015) Nitidine chloride induces apoptosis in human hepatocellular carcinoma cells through a pathway involving p53, p21, Bax and Bcl-2. Oncol Rep 33:1264-1274

Platas CS, Garcia N, Sada EF et al (2012) Cardiotoxicity of acetogenins from Persea americana occurs through the mitochondrial permeability transition pore and caspase-dependent apoptosis pathways. J Bioenerg Biomembranes 44:461-471

Qi F, Zhou A, Yan L et al (2020) The diagnostic value of PIVKA-II, AFP, AFP-L3, CEA, and their combinations in primary and metastatic hepatocellular carcinoma. J Clin Lab Anal 34(5):e23158

Raghunandhakumar S, Paramasivam A, Senthilraja S et al (2013) Thymoquinone inhibits cell proliferation through regulation of G1/S phase cell cycle transition in $\mathrm{N}$-nitrosodiethylamineinduced experimental rat hepatocellular carcinoma. Toxicol Lett 223:60-72

Rainey C, Affleck M, Bretschger K, Alfin-Slater RB (1994) The California avocado, a new look. Nutr Today 29:23-27

Rajkapoor B, Murugesh N, Chodon D, Sakthisekaran D (2005) Chemoprevention of $\mathrm{N}$-nitrosodiethylamine induced phenobarbitol promoted liver tumors in rat by extract of Indigofera aspalathoides. Biol Pharm Bull 28:364-366

Reuter BK, Asfaha S, Buret A, Sharkey KA, Wallace JL (1996) Exacerbation of inflammation-associated colonic injury in rat through inhibition of cyclooxygenase-2. J Clin Invest 98(9):2076-2085

Reyes-Gordillo K, Shah R, Muriel P et al (2017) Oxidative stress and inflammation in hepatic diseases: current and future therapy. Oxid Med Cell Longev 2017:3140673

Rodríguez-Carpena JG, Morcuende D, Estévez M (2011) Avocado byproducts as inhibitors of color deterioration and lipid and protein oxidation in raw porcine patties subjected to chilled storage. Meat Sci 89:166-173

Sadek AM, Mohammed IA, Fatma AK, Lamiaa AA, Barakat NHA, Basma SMS (2012) Impact of Actinidia deliciosa (Kiwi fruit) consumption on oxidative stress status in carcinogenesis. African J Biol Sci 8:117-127

Sahin K, Orhan C, Tuzcu M et al (2014) Orally administered lycopene attenuates diethylnitrosamine-induced hepatocarcinogenesis in rats by modulating Nrf-2/HO-1 and Akt/mTOR pathways. Nutr Cancer 66:590-598

SampathKumar S, RamaKrishnan N (2011) Chromatographic fingerprint analysis of Naringi crenulata by HPTLC technique. Asian Pac J Trop Biomed 1:S195-S198 
Shi W, Hu J, Zhu S et al (2015) Expression of MTA2 and Ki-67 in hepatocellular carcinoma and their correlation with prognosis. Int J Clin Exp Pathol 8:13083-13089

Simunkova M, Alwasel SH, Alhazza IM et al (2019) Management of oxidative stress and other pathologies in Alzheimer's disease. Arch Toxicol 93:2491-2513

Singh BN, Singh BR, Sarma BK, Singh HB (2009) Potential chemoprevent ion of $\mathrm{N}$-nitrosodiethylamine-induced hepatocarcinogenesis by polyphenolics from Acacia nilotica bark. Chem Biol Interact 181:20-28

Sivaramakrishnan V, Shilpa PN, Praveen-Kumar VR, Niranjali-Devaraj $\mathrm{S}$ (2008) Attenuation of N-nitrosodiethylamine induced hepatocellular carcinogenesis by a novel flavonol-Morin. Chem Biol Interact 171:79-88

Snarska J, Szajda SD, Puchalski Z et al (2006) Usefulness of examination of some tumor markers in diagnostics of liver cancer. Hpatogastroenterology 53(68):271-274

Sparkman DO, Penton Z, Kitson FG (2011) Gas chromatography and mass spectrometry: a practical guide. Academic Press. ISBN 978-0-08-092015-3.

Taha MM, Wahab SI, Othman F, Hanachi P, Ahmad BA, Al-Zubairi AS (2009) In vivo anti-tumor effects of Azadirachta indica in rat liver cancer. Res J Biol Sci 4:48-53

Thanan R, Oikawa S, Hiraku Y et al (2015) Oxidative stress and its significant roles in neurodegenerative diseases and cancer. Int $\mathrm{J}$ Mol Sci 16:193-217
Vousden KH, Prives C (2009) Blinded by the light: the growing complexity of P53. Cell 137:413-431

World Health Organization. Global health observatory. Geneva: World Health Organization; 2018. who.int/gho/database/en/. Accessed Jun 21, 2018.

$\mathrm{Xu}$ J, Wu C, Che X et al (2011) Circulating microRNAs, miR-21, miR122 , and miR-223, in patients with hepatocellular carcinoma or chronic hepatitis. Mol Carcinog 50(2):136-142

Yagi K (1987) Lipid peroxides and human disease. Chem Phys Lipids 45:337-351

Yang CS, Landau JM, Huang MT, Newmark HL (2001) Inhibition of carcinogenesis by dietary polyphenolic compounds. Annu Rev Nutr 21:381-406

Zhang WK, Gu HW, Li XY, Tang H, Tian G, Shang H (2017) The dark side of "the force"- lipid nanoparticles enhance the oncogenesis of diethylnitrosamine and result in liver cancer in mice. Nanomedicine: Nanotech Biol Med 13: 701-711.

Zhao L, Chen J, Su J et al (2013) In vitro antioxidant and antiproliferative activities of 5-hydroxymethylfurfural. J Agric Food Chem 61(44):10604-10611

Publisher's Note Springer Nature remains neutral with regard to jurisdictional claims in published maps and institutional affiliations. 